\title{
A Theoretical Perspective of Contract and Contractual Customer-Supplier Relationship in the Mobile Phone Service Sector
}

\author{
Muhammad Turki Alshurideh ${ }^{1}$ \\ ${ }^{1}$ Associate Professor, Marketing Department, School of Business, The University of Jordan, Jordan \\ Correspondence: Muhammad Turki Alshurideh, Associate Professor, Marketing Department, School of Business, \\ The University of Jordan, Amman, Jordan. E-mail: m.alshurideh@ju.edu.jo
}

Received: January 28, 2017

Accepted: June 2, 2017

Online Published: June 9, 2017

doi:10.5539/ijbm.v12n7p201

URL: https://doi.org/10.5539/ijbm.v12n7p201

\begin{abstract}
Both contracts and contractual relationships as concepts have been rarely discussed from scholars' perfectives in the Relationship Marketing (RM) branch of learning. Reviewing these concepts in the customer-service sector adds value because the majority of mobile service firms are losing their current contracted customers at a significant rate despite practicing different RM activities to retain active ones. Thus, this study introduces the concept of Contractual Customer Relationship Marketing (C-CRM) for the first time to the RM field of study and discusses how to employ Contractual Relationship Marketing (C-RM) especially in the use of contractual bonds to establish, maintain and extend customer-supplier relationships.

This study targets various issues that are interrelated to the use of contracts to maintain and retain valuable customers in the mobile service sector. To explore these issues, this paper focuses on extending an understanding of contracts and their use in the contractual customer-supplier relationships. This requires an overview of the study's topic in section one, with section two outlining the study's importance. Section three provides an overview of the contract meaning and section four explaining the main benefits of using business contracts. Section five discusses the importance of using contracts for customer retention, then section six considers the contractual use in renewable situations, section seven reviews the relationship between contract use and customer switching, section eight explains how to employ contracts in prolonging customer-supplier relationships, and, finally, the concluding remarks are made in section nine.
\end{abstract}

Keywords: contract, contractual relationship, customer retention, contract benefits, renewable contracts, customer longevity, customer switching

\section{Introduction}

Studying customer-retention behaviour in the contractual and non-contractual mobile purchasing settings is essential, especially when the goal is to establish long-term customer relationships based on mutual motives which determine their future exchanges (Furinto et al., 2009; Svahn \& Westerlund, 2009; Alshurideh, 2016a). This long-term customer relationship need was confirmed by Sheth and Parvatiyar (1995) who also identified that literature investigating behavioural retention motivations related to theories of relationship marketing within the customer markets was limited, while there was extensive literature on supplier markets. Even in industrial services, there is not a great deal of literature on the contractual relationship phenomenon and its related behaviour studies as the majority of previous studies focused on contractual outsourcing issues for some service operations and services maintenance (Lai et al., 2006; Panesar \& Markeset, 2008). However, some transaction exchanges were seen to be contractual transactions rather than relational ones (Dubois \& Gadde, 2000). Thus, additional research is required to explore contractual and non-contractual customer retention behaviour especially within the individual level of analysis (Reinartz \& Kumar, 2000).

This study adds value to the understanding of contractual relationship marketing (C-RM) among two parties by exploring issues that have rarely been discussed before, especially within the service contractual setting. In addition, the study tries to find suitable answers to questions pertaining to relationship marketing, including the following: What does a contract mean? What are the benefits of contracts? How are contracts used for customer retention? Why and how are contracts renewable? The role a contract plays in decreasing customer switching? Lastly, how to employ contract longevity in relationships to extend the mutual customer-supplier relationship? 


\section{Study Importance}

Numerous published studies have examined the customer-supplier relationship phenomena in-depth and some have identified significant motives for customer retention and loyalty (Patterson, 2007). However, few studies have considered why customers prefer to continue purchasing from the same service provider especially in both the contractual and non-contractual behaviour settings. Moreover, these studies have not provided information with regard to what suppliers should do, from a behavioural perspective, to maintain their customers by using contractual bonds. As a result, this study adds further value to the literature by investigating how firms can use regulatory bonds (for example, contractual bonds) in addition to other bonds (for example, economic or social) to build and extend formal mutual relationships with existing users (Helm et al., 2006; Sweeney \& Webb, 2007; Alshurideh et al., 2016).

More importantly, research is needed to study how contracts can be used to maintain a contractual relationship between two parties to achieve the shared purposes and to increase the shared relationship values (Robinson et al., 1994; Alshurideh, 2016c). Although a customer-supplier contractual relationship has received less attention from scholars, an analysis of such contractual relationship literature has revealed that fewer studies have investigated the use of contracts to maintain firm-employee relationships (Rousseau, 1995; Herriot \& Pemberton, 1997).

Sustaining the customer-firm relationship, especially in the contractual context, to create relationship continuity requires many elements, some of which have been illustrated in previous studies such as mutual goals (Wilson, 1995), shared values (Morgan \& Hunt, 1994), cooperation (Anderson \& Narus, 1990; Chen, 2005), satisfaction (Ranaweera \& Prabhu, 2003; Alshurideh et al., 2012b), trust (Schurr \& Ozanne, 1985), commitment (Moorman et al., 1992), structural bonds (Sang-Lin et al., 1993; Wilson, 1995), contractual bonds (Alshurideh, 2016a; Alshurideh, 2016b; Alshurideh, 2016c), social bonds (Wilson, 1995), comparison level of the alternatives (Anderson \& Narus, 1984; Anderson \& Narus, 1990), exit barriers (Dwyer et al., 1987), and switching costs (Sengupta \& Krapfel, 1997; Burnham et al., 2003). In some cases, the mutual relationship requires other factors, such as interdependence and power (Anderson \& Weitz, 1990), non-retrievable investments (Wilson, 1995), and shared technology (Sang-Lin et al., 1993; Vlosky \& Wilson, 1994). However, additional attention is required when analysing how to use the contractual bonds as a determinant to establish long-term customer-supplier relationships and maintain customer retention. This is due to the commitment of partners in a mobile contract which explains why it is essential to renew contacts and keep the business running when each party has delivered the promised benefits and penalties.

While a customer is looking to have a long-term relationship with one of the mobile suppliers, he or she is sometimes not sure of the extent to which the supplier will treat him or her properly and fulfil future contract promises (Ravald \& Gronroos, 1996). Therefore, to avoid some of the customer's psychological, financial or even social-relationship costs, which are considered important, a customer looks to form a relationship with a well-known branded supplier. Such a supplier has earned positive publicity and recommendations from other customers, even if this means paying more for specific types of mobile services (Jarvis \& Wilcox, 1977; Jevons et al., 2002). These elements will help to enhance the supplier's overall image, which justifies repeat purchase behaviour.

\section{Contract Meaning?}

The majority of service organizations deliver their services through long-term contracts, especially the mobile phone sector. A contract is defined as "a promise or set of promises for the breach of which the law provides a remedy or for the performance of which the law recognizes a duty" (Muroff et al., 2004, p.459). Based on Muroff et al's (2004) definition, two main principles remain important in contract constructions. Firstly, a contract is a well-written document that encompasses a promise or mutual promises of intentions, which bind the agreed obligations between the contracting parties. Secondly, the law enforces a contract's obligations and promises. The formal construct of a contract defines its actions' promissory nature, determines its agreed attributes supported by describing interrelated service quality that distinguish the intent and bind of both contracted relationship parties (Roehling, 1997; Al-Dmour et al., 2014).

In most cases, a contract is used by service firms as a basic tool in the interaction process which defines the shape of the relationship and which contains three main elements. Firstly, it defines types and levels of property right exchanges between the two parties; and, secondly, it includes both implicit and explicit content of exchange processes which define the type and level of formality and informality of the interaction process. Thirdly, it sets out the degree of involvement and the communication types as well as methods involved in the interactions (Janssen \& Joha, 2004). Accordingly, there are many issues that should be explained clearly when constructing 
the mobile contract between the parties involved, such as the legal ramifications of contract duration, automatic termination and renewal conditions.

This study inspects the contractual relationship issue and gives examples from different mobile markets around the world. Wireless telecommunication services are mainly provided by mobile phone suppliers using two subscription methods, namely, prepaid and post-paid. For the purposes of this study, the contractual behaviour situation can be described as one in which a customer signs a contract with one or more of the wireless telecommunication service providers, which is known as post-paid subscription. The non-contractual behaviour situation is described as the prepaid situation, where there is no need for a customer to sign a contract with any of the wireless telecommunication service providers, which is known for some marketers as "Pay-as-you-Go".

Wireless communication services are controlled by law, which is defined by specific rules that control such interaction. A large part of any contract presents and defines a code of conduct that encompasses many rules and conditions; these define and control the future interactions between customer and suppliers for a specific period of time and can be renewed for additional periods of time. Two elements need to be explained regarding the contract from a behavioural perspective. Firstly, the contractual data which covers many elements that ensure that interactions and it is circumstances between both relationship parties run efficiently without any violations (Alshurideh, 2010 cited Wei \& Chiu, 2002). Secondly, the contractual relationship requirements, which are described clearly and classified by Panesar (2008, cited in Thompson et al., 1998) into four main elements, namely, (a) the relationship between the involved parties, (b) the responsibilities of each party, (c) the sharing risk of events and actions in a contract, and (d) the reimbursements structure. These elements usually act together to define and shape the contractual relationship between any two parties. Some questions may arise and one of them would be what the benefits are of using contracts in organizing the relationship between customers and suppliers?

\section{Contract Benefits}

In changeable and uncertain business environments, written contracts offer many benefits for both customers and suppliers. These benefits include determining and protecting benefits in the long-term, giving adequate protection for both parties and motivate them to do their duties adequately, minimizing and managing perceived risks, managing the internal and external contracting process with a variety of business bodies and customers, and delivering the multi-functional tools between the relationship parties (Levine, 2003; Gutiérrez et al., 2004; Koford \& Miller, 2006; Alshurideh et al., 2015; Alshurideh, 2016a). Moreover, a contract is useful in many other business issues, such as determining the future demand for a variety of products and services, organizing business relationships between different partners, especially when a network of relationships is needed to serve customers properly (for example, inventory and outsourcing systems), as well as investigating consumer behaviour, reactions and future trends in many services, especially for new offerings (Taylor, 1980; Tekleab et al., 2005). In addition, written contracts make it possible for both parties to initiate, maintain and eventually terminate their mutual relationship without dispute. By having the conditions and terms recorded in a written document, it is possible for both parties to respond to any possible changes in business conditions, allowing them to cancel, renew or upgrade their commitments. In the presence of varying circumstances, a contract can help in controlling both parties' decisions and facilitating business continuation (Goldberg, 1976).

\section{Contracts and Customer Retention}

For customer retention, the contract is the primary tool used to organize simple and complex consumer-supplier relationship exchanges to the degree that both parties are committed to contract obligations, benefits and penalties over the contract period (Gutiérrez et al., 2004). Contracts commit both parties to the relationship by managing many interactive behavioural and non-behavioural related dimensions such as dependence, power, cooperation, conflict, trust, commitment, switching barriers, switching costs, exchange content, transaction costs, mutual bonds, customization and uncertainty reduction. According to Sharma et al. (2006) as well as Kim and Frazier (1997), five commitment dimensions relating to mutual contracts have been determined, including locked-in, behavioural, obligation, affective and value-based. The main contract issues that need more explanation with respect to commitment in the long-term are affective commitment, mutual bonds and locked-in. For Mavondo and Rodrigo (2001), affective commitment is determined by affective and/or normative attachments that define the strength and level of consumer intent to remain in a relationship with a supplier. Affective commitment shapes the degree to which a relationship is maintained in the long-term. Also, consumers must define what attachments and bonds need to be secured by law via a contract document in order for them to enter a long-term contractual relationship and commit to it (De Ruyter et al., 2001). Some authors have also described these bonds as relationship attachments. Nummela (2003) explained that the magnitude of the 
attachment is defined by the degree to which a customer is committed to a relationship and wishes to renew his/her contractual exchange process.

\section{Contract's Renewable Issue}

Some service contracts like mobile phone contracts can be renewed legally and repeatedly based on previous agreements with no changes or additional charges, although they frequently contain written statements that clearly define the contract's renewal and termination conditions (Goldberg \& Erickson, 1987). However, in most cases, contracted partners go through a negotiation process before relationship renewal or termination occurs. When contract negotiations take place, factors that affected the negotiation process for the first contract are different from those that affect the decision to renew a contract. In the case of the latter, firms and customers are more likely to be concerned with the value to be gained and penalties incurred whereas, with regard to the former, consumers are concerned with all aspects of the contract, namely, benefit terms, costs and conditions (Ganesh et al., 2000).

This is because the process of contract renewal has many additional elements that need to be taken into consideration, such as reliability, consistency of service, goods provided, variations in service quality during the contracted period, consumer uncertainty and how to reduce it, substitute mobile offer availability and contract duration. Thus, contract renewal is affected by many factors such as contract price (cost), renewal negotiation process, and contract-related issues such as duration, terms and conditions. Price is essential in the contractual relationship because it determines many elements such as future service usage, level of benefits, and the contract period. For example, in the mobile phone sector, organizations that provide technical elements which require broadband-related services will force mobile operators to set different price levels for these services based on future use (Jonason, 2002).

In addition, renewing contracts provides many benefits for both parties. The primary benefits are price (saving on costs), enhanced quality of products and services, increased mutual cooperation, time and effort saved by not having to search for other alternatives, accumulated previous experiences for both parties, and establishing trust and commitment between contractual partners (Hart et al., 1997; Bolton et al., 2006; Anton et al., 2007; Alshurideh et al., 2012b; Obeidat et al., 2012; Alshurideh, 2014b; Alshurideh et al., 2015; Alshurideh et al., 2017). As service delivery and consumption experience are essential factors for the customer to consider when deciding whether to renew or cancel the contract; these factors are crucial for the supplier's survival (Bolton et al., 2006). The renewal process can also be used as a tool to enhance services provided in different areas such as avoiding repeated mistakes, appraising the contracted product type and brand, reviewing the level and quality of all services continuously which in turn aids in developing long-term business exchange activities (Dalen et al., 2006; Al-dweeri et al., 2017). Lascelles and Dale (1989, in Bradley, et al., 2006a) identified some indirect benefits of contract renewal, for example, some customers use their purchasing muscle to force their suppliers to adopt certain quality management techniques and practices as a contractual condition of business.

\section{Contracts and Customer Switching}

The primary relational goal for any organization is having the long-term continuity of exchange between itself and its customers. Therefore, the "customer retention" trend has emerged to increase organizations' profits and minimize both costs and customer switching in the long-term. This view is confirmed by Farquhar (2003) who explained that to be able to build long-term relationships with customers and retain customers, institutions must first be able to retain existing customers and minimize their switching behaviour. Firms, in general, execute many actions to bond customers and they apply them in different ways. For the purposes of this study, a formal signed contract between a customer and a mobile supplier is considered one of the bonds that suppliers use to lock-in customers, and it is a tool that they also use to maintain their relationships with the customers. For example, Hammarkvist et al. (1982) analysed the dyadic mutual relationship and defined many bonds in their analysis including social, economic, legal and administrative bonds.

Other bonds have been defined by researchers including interpersonal relationship (Lewis, 2000), joint new product development (Comer \& Zirger, 1997), and level of investment in the supplier-customer relationship (Monczka \& Carter, 1988). Additionally, Liang and Wang (2007) defined four additional types of attachments that minimize customer switching, namely, physical, emotional, psychological and economic attachments that enhance the interaction between two parties and foster contracts renewal. Psychological attachment (sometimes known as informational attachment) is essential since it empowers interactive behaviour between both parties in the relationship (Houghton \& Yoho, 2005; Alshurideh, 2014b). Part of the psychological attachment is emotional in that a subscriber expresses a level of confidence in and attraction to a specific operator or network. Some studies have developed the "psychological contract" concept as a bridge that maintains customer-supplier 
relationships (Schein, 1980). A psychological contract is characterized by Rousseau (1995, p.679) as "an individual's belief in mutual obligations between that person and another party such as an employer", which defines the level of one party's judgments of another party's obligations and responsibilities in the mutual relationship. Also, feedback and criticism, which function as positive informational reinforcement, increase the level of contractual psychological attachment, which, in turn, increase the probability of establishing a long-term relationship and increasing customer retention (Verlander \& Evans, 2007).

Service firms use many programs to increase customer lock-in, such as discounts on virtual network, family wireless communication packages, as well as evening and weekend discounts (Yanamandram \& White, 2006). Loyalty programs are also used. According to Colloquy (2000, cited in Lacey \& Sneath, 2006), about $75 \%$ of consumers in the U.S. have participated in at least one loyalty program. Warranties are also considered a good lock-in tool that prevents customers from switching. Warranties provide limited services, such as maintenance contracts, to ensure customers are committed to their suppliers. Morgan and Hunt (1994, p.23) describe being committed as "believing that an ongoing relationship with another is so important as to warrant maximum efforts at maintaining it". Thus, "locking-in" mobile subscribers for long periods is one of the contract dimensions that determine consumer commitment and retention (Lee et al., 2001).

\section{Contract Longevity and Customer Retention}

Mutual relationship classification has been perceived differently within relationship literature, ranging from discrete transactions, through repeated purchase transactions, to long-term relationships, and full partners (Goffin, 2006; Mohr \& Nevin, 1990; Webster, 1992; Alshurideh, 2010a,b). Mainly, scholars have also classified relationship types based on specific factors such as transactions, closeness and longevity (Barnes, 1997; Bove \& Johnson, 2001). Some scholars have relied heavily on employing different relationship time dimensions and have used different related concepts such as relationship longevity or duration (Bolton, 1998; Reinartz \& Kumar, 2003; Fink et al., 2008). However, for Goffin (2006), it is useful to employ time dimensions in relationship classification, but, in most cases, classifying relationships as long- or short-term based on time dimensions is insufficient and useless while a long-term relationship may consist of just a single, small transaction such as the placing of an order and its delivery.

In the mobile phone industry, contract longevity is distributed between two categories, namely, prepaid telecommunication subscription services or post-paid telecommunication subscription services, which are distributed mainly between 6,12,18, and 24-month contracts. According to Tingay (2009), who analysed data on contract length, around $91 \%$ of respondents expressed a preference for contracts lasting 12 months; as this gave them the chance to switch or remain with their current provider, depending on whether they could gain more benefits from a new contract with another service provider or via contract renewal. One of the additional attributes of the mobile phone sector is that it is easy for a mobile user to transfer from non-contractual subscription to contractual subscription at any time and from contractual subscription to non-contractual subscription when his or her contract period finishes.

In addition, a consumer should be able to choose from among a variety of mobile communication contracting options and negotiate renewal issues when his or her contract is about to finish. The second purchase (contract renewal) seems to be easier than the initial purchase (first contract), due to consumers accumulating information, knowledge and experience through direct interactions with the products and services that suppliers offer after their first point of product/service contact. Moreover, in the mobile phone sector, the main customer retention issue of concern to suppliers is the "churn rate". The churn rate in this area is concerned with planning and analysing marketing activities towards accurate predictions of customer retention and turnover for future perspectives (Fader \& Hardie, 2006). Bowes (2008) found that the loss rate within the British mobile telecom sector had increased from $33.4 \%$ in 2005 to $38.6 \%$ in 2007 . Thus, mobile service organizations can work on facilitating the process of making customers transfer from non-contractual status to the contractual ones or even easily upgrading their contracts from low period contracts (for example one month contract) to longer ones (for example six months contract). This can be done easily by highlighting and marketing properly the consequences and accumulated benefits that a customer will gain or highlighting the amount of punishments that a customer will surely redeem after upgrading the service contracts especially in the long-term (Alshurideh, 2010a; Al Kurdi, 2016).

\section{Conclusion}

After discussing what a contract means supported by summarizing the benefits of using such contracts, the mobile contract is seen as a regulatory tool used by service firms to establish and maintain long-term relationships with customers to protect their rights within agreed terms and conditions. In addition, the contract 
is considered a good tool for maintaining an existing customer-supplier relationship when it is adjusted or renewed for another period of time. This is important as Dalen et al. (2006) estimated that about 50\% of contracts are renewed. Thus, suppliers have to give a brief description of the main elements of the contracts and the relative importance of such contract features (Alshurideh, 2016c) because each contract has different terms and conditions defining the basics of mobile phone use as well as the service procedures. Also, contracts have various terms and conditions that regulate the relationship between the subscribers and operators regarding the process of upgrading, renewing and terminating the services. The essential part of a contract is its regulation items, which Baldwin and Cave (1999) describe as relating to activities that restrict behaviour and/or prevent the occurrence of certain undesirable actions.

\section{References}

AL Kurdi, B, H. (2016). Healthy-Food Choice and Purchasing Behaviour Analysis: An Exploratory Study of Families in the UK. Doctoral thesis, Durham University.

Al-Dmour, H., Alshurideh, M., \& Shishan, F. (2014). The influence of mobile application quality and attributes on the continuous intention of mobile shopping. Life Science Journal, 11(10), 172-181.

Al-dweeri, R. M., Obeidat, Z. M., Al-dwiry, M. A., Alshurideh, M. T., \& Alhorani, A. M. (2017). The Impact of E-Service Quality and E-Loyalty on Online Shopping: Moderating Effect of E-Satisfaction and E-Trust. International Journal of Marketing Studies, 9(2), 92-103. http://dx.doi.org/10.5539/ijms.v9n2p92

Alshurideh, M. (2010). A behavior perspective of mobile customer retention: An exploratory study in the UK Market. The End of the Pier? Competing perspectives on the challenges facing business and management British Academy of Management Brighton-UK. British Academy of Management, 1-19.

Alshurideh, M. (2010). Customer Service Retention - A Behavioural Perspective of the UK Mobile Market. Doctoral thesis. Durham University.

Alshurideh, M. (2014). A Qualitative Analysis of Customer Repeated Purchase Behaviour in the UK Mobile Phone Market. Journal of Management Research, 6(1), 109-125. http://dx.doi.org/10.5296/jmr.v6i1.4659

Alshurideh, M. (2014). The Factors Predicting Students' Satisfaction with Universities' Healthcare Clinics' Services: A Case-Study from the Hashemite Kingdom of Jordan. Dirasat, Administrative Science, 41(2), 451-464.

Alshurideh, M. (2016). Is Customer Retention Beneficial for Customers: A Conceptual Background, Journal of Research in Marketing, Journal of Research in Marketing, 5(3), 382-389. http://dx.doi.org/10.17722/jorm.v5i3.126

Alshurideh, M. Nicholson, M., \& Xiao, S. (2012). The Effect of Previous Experience on Mobile Subscribers' Repeat Purchase Behaviour, European Journal of Social Science. 30(3), 366-376.

Alshurideh, M. T. (2016). Exploring the Main Factors Affecting Consumer Choice of Mobile Phone Service Provider Contracts. Int. J. Communications, Network and System Sciences, 9, 563-581. http://dx.doi.org/10.4236/ijens.2016.912044

Alshurideh, M. T., Al-Hawary, S. I. S., Mohammad, A. M. E., Al-Hawary, A. A., \& Al Kurdi, B. H. (2017). The Impact of Islamic Banks' Service Quality Perception on Jordanian Customers Loyalty. Journal of Management Research, 9(2), 139-159. https://doi.org/10.5296/jmr.v9i2.10664

Alshurideh, M., (2016). Scope of Customer Retention Problem in the Mobile Phone Sector: A Theoretical Perspective. Journal of Marketing and Consumer Research. 20, 64-69.

Alshurideh, M., Al Kurdi, B. H., Vij, A., Obiedat, Z., \& Naser, A. (2016). Marketing Ethics and Relationship Marketing-An Empirical Study that Measure the Effect of Ethics Practices Application on Maintaining Relationships with Customers. International Business Research, 9(9), 78-90. https://doi.org/10.5539/ibr.v9n9p78

Alshurideh, M., Alhadeed, A. Y., \& Barween, A. (2015). The effect of internal marketing on organizational citizenship behavior an applicable study on the University of Jordan employees. International Journal of Marketing Studies, 7(1), 138-145. https://doi.org/10.5539/ijms.v7n1p138

Alshurideh, M., Bataineh, A., Al kurdi, B., Alasmr, N. (2015). Factors affecting Mobile Phone Brand Choices-Studying the Case of Jordan Universities Students. International Business Research, 8(3), 141-155. http://dx.doi.org/10.5539/ibr.v8n3p141

Alshurideh, M., Masa'deh, R., \& Al kurdi, B. (2012). The effect of Customer Satisfaction upon Customer 
Retention in the Jordanian Mobile Market: An Empirical Investigation. The European Journal of Economics, Finance and Administrative Sciences, 47(47), 69-78.

Anderson, C., \& Narus, J. (1984). A Model of the Distributor's Perspective of Distributor-Manufacture. Working Relationships. Journal of Marketing, 48(Fall), 62-74. https://doi.org/10.2307/1251511.

Anderson, C., \& Narus, J. (1990). A Model of Distributor Firm and Manufacturer Firm Working Partnerships. Journal of Marketing, 54(January), 42-58. Doi: 10.2307/1252172

Anderson, E., \& Weitz, B. (1990). Determinants of Continuity in Conventional Industrial Channel Dyads." Marketing Science, 8(3), 10-323. http://dx.doi.org/10.1287/mksc.8.4.310.

Anton, C., \& Camarero, C. et al. (2007). Analysing firms' failures as determinants of consumer switching $\begin{array}{llll}\text { intentions. } \quad \text { European Journal of } & \text { Marketing, 41(1/2), }\end{array}$ http://dx.doi.org/10.1108/03090560710718157

Barnes, J. G. (1997). Closeness, Strength, and Satisfaction: Examining the Nature of Relationships between Providers of Financial Services and Their Retail Customers. Psychology \& Marketing, 14(8), 765-790. https://doi.org/10.1002/(SICI)1520-6793(199712)14:8<765::AID-MAR3>3.0.CO;2-C

Bolton, R. N. (1998). A Dynamic Model of the Duration of the Customer's Relationship with a Continuous Service Provider: The Role of Satisfaction. Marketing Science, 17(1), 45-65. http://dx.doi.org/10.1287/mksc.17.1.45

Bolton, R. N., \& Lemon, K. N. et al. (2006). The Effect of Service Experiences over Time on a Supplier's Retention of Business Customers. Management Science, 52(12), 1811-1823. http://dx.doi.org/10.1287/mnsc.1060.0594

Bove, L. L., \& Johnson, L. W. (2001). Customer relationships with service personnel: do we measure closeness, quality or strength? Journal of Business Research, 54(3), 189-197. https://doi.org/10.1016/S0148-2963(00)00122-3

Bowes, P. (2008). Industry Customer Churn Rate increases 15 percent GeoConnexion - Pitney Bowes Group 1, Geo: International News. Retrieved http://www.geoconnexion.com/geo_news_article/Industry-Customer-Churn-Rate-increases-15-percent/2770

Bradley, F., \& Meyer, R. et al. (2006). Use of supplier-customer relationships by SMEs to enter foreign markets. Industrial Marketing Management, 35(6), 652-665. https://doi.org/10.1016/j.indmarman.2005.05.005

Burnham, T. A., \& Frels, J. K. et al. (2003). Consumer Switching Costs: A Typology, Antecedents, and Consequences. Journal of the Academy of Marketing Science, 31(2), 109-126. https://doi.org/10.1177/0092070302250897

Chen, H. H. (2005). Cooperative Performance: Factors Affecting the Performance of International Technological Cooperation, Universal-Publishers.

Comer, J. M., \& Zirger, B. J. (1997). Building a supplier-customer relationship using joint new product $\begin{array}{llll}\text { development. Industrial } & \text { Marketing 203-211. }\end{array}$ https://doi.org/10.1016/S0019-8501(96)00114-9

Dalen, D. M., E. R. Moen, et al. (2006). Contract renewal and incentives in public procurement. International Journal of Industrial Organization, 24(2), 269-285. Doi:10.1016/j.jindorg.2005.04.004

De Ruyter, K., \& Moorman, L. et al. (2001). Antecedents of Commitment and Trust in Customer-Supplier Relationships in High Technology Markets. Industrial Marketing Management, 30(3), 271-286. https://doi.org/10.1016/S0019-8501(99)00091-7

Dubois, A., \& Gadde, L. E. (2000). Supply strategy and network effects -- purchasing behaviour in the construction industry. European Journal of Purchasing \& Supply Management, 6(3-4), 207-215. https://doi.org/10.1016/S0969-7012(00)00016-2

Dwyer, F. R., \& Schurr, P. H. et al. (1987). Developing Buyer-Seller Relationships. Journal of Marketing, 51(2), 11-27. http://dx.doi.org/10.1108/EUM0000000004910

Fader, P., \& Hardie, B. (2006). How to Project Customer Retention. Social science research network: The Wharton School, University of Pennsylvania. 1-26. http://dx.doi.org/10.2139/ssrn.801145

Farquhar, J. D. (2003). Retaining customers in traditional retail financial services: interviewing 'les responsables'. International Review of Retail, Distribution \& Consumer Research, 13(4), 393-405. 
https://doi.org/10.1080/0959396032000129499

Fink, R. C., \& James, W. L. et al. (2008). The effects of performance, environmental uncertainty and relational norms on customer commitments to suppliers over the duration of customer-supplier relationships. International Journal of Management and Decision Making, 9(6), 660-685. http://dx.doi.org/10.1504/IJMDM.2008.02122

Furinto, A., \& Pawitra, T. et al. (2009). Designing competitive loyalty programs: How types of program affect customer equity. Journal of targeting, Measurement and Analysis for Marketing 17, 307-319. http://dx.doi.org/10.1057/jt.2009.20

Ganesh, J., \& Arnold, M. J. et al. (2000). Understanding the Customer Base of Service Providers: An Examination of the Differences between Switchers and Stayers. Journal of Marketing, 64(3), 65-87. http://dx.doi.org/10.1509/jmkg.64.3.65.18028

Goffin, K., \& Lemke, F. et al. (2006). An exploratory study of 'close' supplier-manufacturer relationships. Journal of Operations Management, 24(2), 189-209. http://dx.doi.org/10.1016/j.jom.2005.05.003

Goldberg, V. P. \& Erickson, J. R. (1987). Quantity and price adjustment in long-term contracts: A case study of petroleum coke. Journal of Law and Economics, 30(2), 369-398. http://dx.doi.org/10.1086/467141

Goldberg, V. P. (1976). Regulation and administered contracts. The Bell Journal of Economics, 7(2), 426-448. http://dx.doi.org/10.1007/BF00134817

Gutiérrez, S. S., J. G. Cillán, et al. (2004). The consumer's relational commitment: main dimensions and antecedents. Journal of Retailing and Consumer Services, 11(6), 351-367. http://dx.doi.org/10.1016/j.jretconser.2003.12.001

Hammarkvist, K. O., \& Håkansson, H. et al. (1982). Marknadsföring för konkurrenskraft. Malmö, Liber.

Hart, O., \& Shleifer, A. et al. (1997). The proper scope of government: theory and an application to prisons. The Quarterly Journal of Economics, 112(4), 1127-1161. http://dx.doi.org/10.3386/w5744

Helm, S., \& Rolfes, L. et al. (2006). Suppliers' willingness to end unprofitable customer relationships. European Journal of Marketing, 40(3/4), 366-383. http://dx.doi.org/10.1108/03090560610648101

Herriot, P., \& Pemberton, C. (1997). Facilitating new deals. Human Resource Management Journal, 7(1), 45-56. http://dx.doi.org/10.1111/j.1748-8583.1997.tb00273.x

Houghton, J. D., \&. Yoho, S. K. (2005). Toward a contingency model of leadership and psychological empowerment: when should self-leadership be encouraged? Journal of Leadership \& Organizational Studies, 11(4), 65-83. http://dx.doi.org/10.1177/107179190501100406

Janssen, M., \& Joha, A. (2004). Issues in Relationship Management for Obtaining the Benefits of a Shared Service Centre. Sixth International Conference on Electronic Commerce. http://dx.doi.org/10.1145/1052220.1052249

Jarvis, L. P., \& Wilcox, J. B. (1977). True vendor loyalty or simply repeat purchase behavior? Industrial Marketing Management, 6(1), 9-14. http://dx.doi.org/10.1016/0019-8501(77)90027-X

Jevons, C., \& Gabbott, M. et al. (2002). A taxonomy of brand linkages: the brand-relationship-interaction (BRI) matrix. White paper, 1-10.

Jonason, A. (2002). Innovative pricing effects: Theory and practice in mobile Internet networks. European Journal of Innovation Management, 5(4), 185-193. http://dx.doi.org/10.1108/14601060210451144

Kim, K. \& Frazier, G. L. (1997). Measurement of distributor commitment in industrial channels of distribution. Journal of Business Research, 40(2), 139-54. http://dx.doi.org/10.1016/S0148-2963(96)00284-6

Koford, K., \& Miller, J. B. (2006). Contract enforcement in the early transition of an unstable economy. Economic Systems, 30(1), 1-23. http://dx.doi.org/10.1016/j.ecosys.2005.08.002

Lacey, R., \& Sneath, J. Z. (2006). Customer loyalty programs: Are they fair to consumers? Journal of Consumer Marketing, 23(7), 458-464. http://dx.doi.org/10.1108/07363760610713000

Lai, J. H. K., \& Yik, F. W. H. et al. (2006). Critical contractual issues of outsourced operation and maintenance service for commercial buildings. International Journal of Service Industry Management, 17(4), 320-343. http://dx.doi.org/10.1108/09564230610680640

Lee, J., \& Lee, J. et al. (2001). The impact of switching costs on the customer satisfaction-loyalty link: mobile 
phone service in France. Journal of Services Marketing, 15(1), 35-48. http://dx.doi.org/10.1108/08876040110381463

Levine, A. (2003). The distributor customer contract. Industrial Distribution, 92(2).

Lewis, J. M. (2000). Repairing the Bond in Important Relationships: A Dynamic for Personality Maturation. Am J Psychiatry, 157(9), 1375-1378. http://dx.doi.org/10.1176/appi.ajp.157.9.1375

Liang, C. J., \& Wang, W. H. (2006). The behavioural sequence of the financial services industry in Taiwan: Service quality, relationship quality and behavioural loyalty. Service Industries Journal, 26(2), 119-145. http://dx.doi.org/10.1080/02642060500369131

Mavondo, F. T., \& Rodrigo, E. M. (2001). The effect of relationship dimensions on interpersonal and inter-organizational commitment in organizations conducting business between Australia and China. Journal of Business Research, 52(2), 111-121. http://dx.doi.org/10.1016/S0148-2963(99)00064-8

Mohr, J., \& Nevin, J. R. (1990). Communication Strategies in Marketing Channels: A Theoretical Perspective. The Journal of Marketing, 54(4), 36-51. http://dx.doi.org/10.2307/1251758

Monczka, R. M., \& Carter, J. R. (1988). Implementing electronic data interchange. Journal of Purchasing and Materials Management, 24(2), 2-9. http://dx.doi.org/10.1080/07421222.1994.11518044

Moorman, C., \& Zaltman, G. et al. (1992). Relationships between providers and users of marketing research: The dynamics of trust within and between organizations. Journal of Marketing Research, 29(3), 314-329. http://dx.doi.org/10.2307/3172742

Morgan, R. M., \& Hunt, S. D. (1994). The Commitment-Trust Theory of Relationship Marketing. Journal of Marketing, 58(3), 20-38. http://dx.doi.org/10.2307/1252308

Muroff, J. A., \& Muroff, L. R. (2004). Contracts in radiology practices: Contract types and key provisions. Journal of the American College of Radiology, 1(7), 459-466. http://dx.doi.org/10.1016/j.jacr.2004.01.023

Nummela, N. (2003). Looking through a prism-multiple perspectives to commitment to international R\&D collaboration. Journal of High Technology Management Research, 14(1), 135-48. http://dx.doi.org/10.1016/S1047-8310(03)00008-7

Obeidat, B., Sweis, R., Zyod, D., Masa'deh, R., \& Alshurideh, M. (2012). The Effect of Perceived Service Quality on Customer Loyalty in Internet Service Providers in Jordan. Journal of Management Research, 4(4), 224-242. http://dx.doi.org/10.5296/jmr.v4i4.2130

Panesar, S. S., \& Markeset, T. (2008). Industrial service innovation through improved contractual relationship. Journal of Quality in Maintenance Engineering, 14(3), 290-305. http://dx.doi.org/10.1108/13552510810899481

Patterson, P. G. (2007). Demographic correlates of loyalty in a service context. Journal of Services Marketing, 21(2), 112-121. http://dx.doi.org/10.1108/08876040710737877

Ranaweera, C., \& Prabhu, J. (2003). The influence of satisfaction, trust and switching barriers on customer retention in a continuous purchasing setting. International Journal of Service Industry Management, 14(4), 374-395. http://dx.doi.org/10.1108/09564230310489231

Ravald, A., \& Gronroos, C. (1996). The value concept and relationship marketing. European Journal of Marketing, 30(2), 19-30. http://dx.doi.org/10.1108/03090569610106626

Reinartz, W. J., \& Kumar, V. (2003). The Impact of Customer Relationship Characteristics on Profitable Lifetime Duration. Journal of Marketing, 67(1), 77-99. http://dx.doi.org/10.1509/jmkg.67.1.77.18589

Robinson, S. L., \& Kraatz, M. S.et al. (1994). Changing obligations and the psychological contract: A longitudinal study. Academy of Management Journal, 37(1), 137-152. http://dx.doi.org/10.2307/256773

Roehling, M. V. (1997). The origins and early development of the psychological contract construct. Journal of Management History, 3(2), 204-217. http://dx.doi.org/10.1108/13552529710171993.

Rousseau, D. M. (1995). Psychological contracts in organizations: Understanding written and unwritten agreements. CA: Sage Publications.

Sang-Lin, H., \& Wilson, D. et al. (1993). Buyer-Seller Relationships Today. Industrial Marketing Management, 22(4), 331-338. http://dx.doi.org/10.1016/0019-8501(93)90029-7

Schein, E. H. (1980). Organizational Psychology. Englewood, Prentice-Hall. 
Schurr, P., \& Ozanne, J. (1985). Influences on Exchange Processes: Buyers' Preconceptions of a Seller's Trustworthiness and Bargaining Toughness. Journal of Consumer Research, 11(March), 939-953. http://dx.doi.org/http://dx.doi.org/10.1086/209028

Sengupta, S., \& Krapfe, R. (1997). Switching costs in account relationships. Journal of Personal Selling and Sales Management, 17(4), 9-16. http://dx.doi.org/10.1080/08853134.1997.10754106

Sharma, N., \& Young, L. et al. (2006). The commitment mix: Dimensions of commitment in international trading relationships in India. Journal of International Marketing, 14(3), 64-91. http://dx.doi.org/10.1509/jimk.14.3.64

Sheth, J., \& Parvatiyar, A. (1995). The evolution of relationship marketing. International Business Review, 4(4), 397-418. http://dx.doi.org/10.1016/0969-5931(95)00018-6

Svahn, S., \& Westerlund, M. (2009). Purchasing strategies in supply relationships. Journal of Business \& Industrial Marketing, 24(3/4), 173-181. http://dx.doi.org/10.1108/08858620910939723

Sweeney, J. C., \& Webb, D. A. (2007). How functional, psychological, and social relationship benefits influence individual and firm commitment to the relationship. Journal of Business \& Industrial Marketing, 22(7), 474-488. http://dx.doi.org/10.1108/08858620710828854

Taylor, J. B. (1980). Aggregate dynamics and staggered contracts. The Journal of Political Economy, 88(1), 1-23. http://dx.doi.org/10.1086/260845

Tekleab, A. G., \& Takeuchi, R. et al. (2005). Extending the chain of relationships among organizational justice, social exchange, and employee reactions: The role of contract violations. Academy of Management Journal, 48(1), 146-157. http://dx.doi.org/10.5465/AMJ.2005.15993162

Thompson, I., \& Cox, A.et al. (1998). Contracting strategies for the project environment - A programme for change. Eursopean Journal of Purchasing and Supply Management, 4(1), 31-41. http://dx.doi.org/10.1016/S0969-7012(98)00005-7

Tingay, D. (2009). Consumer Focus priorities in the mobile phone sector a position paper and advocacy plan. Consumer Focus. Retrieved from http://www.consumerfocus.org.uk/assets/1/files/2009/11/ConsumerFocusprioritiesinthemobilephonesectorO ctober2009.pdf

Verlander, E. G. \& Evans, M. R. (2007). Strategies for improving employee retention. Clinical Leadership \& Management Review, 21(2), 1-8.

Vlosky, R., \& Wilson, D. (1994). Technology Adoption in Channels. Relationship Marketing: Theory Methods and Applications. Centre for Relationship Marketing: Emory University, Conference Proceedings.

Webster, F. E., Jr. (1992). The Changing Role of Marketing in the Corporation. The Journal of Marketing, 56(4), 1-17. http://dx.doi.org/10.2307/1251983

Wilson, D. T. (1995). An Integrated Model of Buyer-Seller Relationships. Journal of the Academy of Marketing Science, 23(4), 335-345. http://dx.doi.org/ 10.1177/009207039502300414

Yanamandram, V., \& White, L. (2006). Switching barriers in business-to-business services: a qualitative study. International Journal of Service Industry Management, $17(2), \quad$ 158-192. http://dx.doi.org/10.1108/09564230610656980

\section{Copyrights}

Copyright for this article is retained by the author(s), with first publication rights granted to the journal.

This is an open-access article distributed under the terms and conditions of the Creative Commons Attribution license (http://creativecommons.org/licenses/by/4.0/). 